\title{
ECTOPIC PREGNANCY AS A COMPLICATION OF ASSISTED REPRODUCTIVE TECHNIQUES FOLLOWING BILATERAL SALPHINGECTOMIES
}

\author{
BILATERAL SALPENJEKTOMI SONRASI UYGULANAN YARDIMLA ÜREME \\ TEKNIKLERININ BIR KOMPLIKASYONU OLARAK OLUŞAN EKTOPIK GEBELIK \\ OLGUSU
}

\author{
Murat KESKİN*, Meryem EKEN**, Ecmel IŞIK KAYGUSUZ***, Murat APİ**, \\ Tuna EREKUL**
}

\begin{abstract}
Ectopic pregnancy continues to be one of the important reasons for maternal mortality. With the widespread and frequent use of Assisted Reproductive Techniques (ART), the frequency of abnormally located pregnancies also rises. In this article, we presented a case of an ectopic pregnancy occurring in the right tubal stump after an intracytoplasmic sperm injection - embryo transfer performed on a 39 year-old patient with secondary infertility and bilateral salphingectomy.

Although a bilateral salphingectomy was performed in IVF cycles for an early diagnosis in order to decrease maternal morbidity and mortality, an ectopic pregnancy in the stump should be definitely taken into consideration in cases where no intrauterine pregnancy is observed.
\end{abstract}

Key Words: Ectopic pregnancy;Bilateral salphingectomy;Assisted Reproductive Techniques (ART)

\section{ÖZET}

Ektopik gebelik halen maternal mortalitenin önemli nedenlerinden biri olmaya devam etmektedir. Yardımla Üreme Teknikleri (YÜT)' nin yaygın ve sık kullanılması ile birlikte anormal yerleşimli gebeliklerin sıklığı da artmaktadır. Bu yazıda 39 yaşında sekonder infertil ve bilateral salpenjektomili hastaya uygulanan intrasitoplazmik sperm injeksiyonu embryo transferi sonrası sağ tubal stump ta meydana gelen ektopik gebelik vakasını sunduk.

Maternal morbidite ve mortaliteyi azaltmak amacıyla erken tanı için IVF sikluslarında bilateral salpenjektomi yapılmış olsa da intrauterin gebelik izlenmediği durumlarda ayırıcı tanıda mutlaka stumpta ektopik gebelik düşünülmelidir.

Anahtar Sözcükler: Ektopik gebelik; Bilateral salpenjektomi; Yardımla üreme teknikleri(YÜT)

\section{INTRODUCTION}

Ectopic pregnancy is still one of the important causes of maternal mortality(1). With the widespread and frequent use of Assisted Reproductive Techniques (ART), the frequency of abnormally located pregnancies also rises (2).Though rare for patients with bilateral salphingectomy, there are reports of interstitial (3), ovarian (4), retroperitoneal (5) and subpancreatic (6) pregnancies.

A case of ectopic pregnancy, occurring in the tubal stump following the ART performed on the patient who underwent bilateral salphingectomy in our hospital is presented here in light of relevant literature.

CASE

A 39-year old woman, had been married for 6 years, gravidity 3 , parity 1 , had previously one spontaneous pregnancy which resulted as a biochemical abortus. At the end of a year she did not conceive and she applied to our infertility outpatient clinic. After general examination she underwent routine infertility tests including ovarian reserve test, spermiogram and sperm morphology and hysterosalpingography(HSG). HSG revealed unilateral hydrosalpinx.

Date received/Dergiye geldiği tarih: 26.02.2015 - Dergiye kabul edildiği tarih: 10.03.2015

* Yeniyüzyıl University Medical Faculty, GaziosmanPaşa Hospital, İstanbul, TÜRKİYE

Zeynep Kamil Educational and Research Hospital, ** Department of Obstetrics and Gynaecology, *** Department of Pathology, İstanbul, TÜRKIYYE

(İletişim kurulacak yazar: meryemkurek@yahoo.com) 
In 2012, due to right tubal ectopic pregnancy and left hydrosalpinx, a laparoscopic bilateral salpingectomy was performed on the patient. The pathological findings revealed trophoblastic cells compatible with tubal pregnancy in the right tube and chronic salpingitis in the left tube.

After failure of the first attempt, she conceived after the second intracytoplasmic sperm injection-embryo transfer (ICSI-ET) in 2014, however pregnancy was terminated at 28 th weeks of gestation as a result of spontaneous contractions and cervical dilatation. On the seventh day of delivery, infant died as a result of acute respiratory distress syndrome.

In 2015, a third ICSI-ET was performed and on the third day, two embryos were transferred. The following results were observed: on the 14th day of embryo transfer Beta hCG $72 \mathrm{IU} / \mathrm{ml}, 17$. day $253 \mathrm{IU} / \mathrm{ml}$, 19.day $633 \mathrm{IU} / \mathrm{ml}, 25$. day $3879 \mathrm{IU} / \mathrm{ml}$.

She admitted to our emergency service complaining of stomachache at the 28th day of embriyo transfer. We obtained normal vital findings, beta hCG level 8543 $\mathrm{IU} / \mathrm{ml}, 12 \mathrm{~mm}$ thickness of endometrium, no gestational sac in the uterine cavity, normal ovaries and mass including hyper-hypoechogenic regions, with a size of $20 \times 12 \mathrm{~mm}$ at the right adnexial site in the transvaginalultrasonography.

Results of our clinical examinations and tests indicated an ectopic pregnancy located on the right remnant tube and she underwent laparoscopic surgery. During surgical exploration an ectopic pregnancy on the right proximal stump was observed at a size of $20 \times 20 \mathrm{~mm}$. It was then resected and an endometrial curettage was performed.

Histopathological examination reported secretory phase in endometrial tissue and gestational material located in the right remnant tube.

\section{DISCUSSION}

Ectopic pregnancy makes up $1,7 \%-2 \%$ of all pregnancies obtained through ART (7). In addition, there are some publications indicating that the rates of ectopic pregnancy through ART are higher than spontaneous pregnancies (8).

Even though ectopic pregnancy is often seen as a complication of ART, it is rarely observed in the proximal tubal stump among patients who underwent bilateral salphingectomy. Po-Chun et al reported its incidence as $0.4 \%$ (9).

The rates of pregnancy through ART in cases with hydrosalpinx is low, bilateral salpingectomy is frequently performed to increase pregnancy rates (10).

This approach leads to one extra surgical intervention in these patients just before ART(11).

The mechanism of post-ART ectopic pregnancies can originate from the direct transfer of embryo to the tube or migration of the embryo from the endometrial cavity to the tube. The embryo transfer technique (deep fundal transfer), use of a transfer medium with a high volume, multiple embryo transfer, frozen embryo transfer, artificial insemination can all increase the possibility of ectopic pregnancies (8). As in our case, two embryos were easily transferred into the fundus by a softcatheter under the guidance of ultrasonography.

Despite bilateral salphingectomy, the nature of ectopic pregnancies are yet not exactly known; moreover, appropriate methods and surgical techniques that can decrease the risk of ectopic pregnancies, such as the correct and proper cauterization of the tubal stump, needs futher investigation (3).

Researchers have not yet demonstrated whether it is possible to prevent this kind of ectopic pregnancy or not. If a complete tubal resection is performed during the first salphingectomy, an ectopic pregnancy on the isthmic part of the remnant tube would be theoretically blocked. However, there are some reports of a spontaneous formation of interstitial/cornual pregnancy following the ipsilateral salphingectomy $(12,13)$. Therefore, even if the tube is completely resected, it can be difficult to prevent the development of ectopic pregnancy in the remnant tube after the ipsilateral salphingectomy (9).

Agarwal et al reported cases of corneal pregnancy in seven patients who underwent a salphingectomy before IVF-ET (14). Po-Chun et al reported six cases of tubal stump pregnancy, four of which occurred after ART (9). The use of ART has led to a considerable increase in tubal stump pregnancies. Against the risk of rupture in the early phase, a rigorous transvaginal ultrasonographic evaluation should be made especially for patients who undergo a salphingectomy, whose Bhcg values are lower than normal or do not exhibit a regular increase (9).

It should be kept in mind that the previous surgery of bilateral salpingectomy can be associated with a missed diagnosis of ectopic pregnancy which may result in a life threatening intraabdomial bleeding (15).

Our case report shows that despite history of bilateral salpingectomy, an ectopic pregnancy can be encountered after ART and present with life threatening results. Clinicans should always be suspicious for the rare conditions to save life.

\section{REFERENCES}

1. Khan KS, Wojdyla D, Say L, Gulmenzoglu AM, van Look PF. WHO analysis of causes of maternal death:a systematic review. Lancet 2006;367:106674.

2. Tal S, Einat PS, Eylon L, Ofer F, Adrian E.Unusual case of recurrent heterotopic pregnancy after bilateral salpingectomy and literature review. RBM Online 2013;26:59-61.

3. Elisabetta G, Lavinia Q, Anna R, Gabriella C, Federica P, Massimo C. Interstitial Pregnancy after In Vitro Fertilization and Embryo Transfer Following Bilateral Salpingectomy: Report of Two Cases and Literature Review. Royan Institute Internat J Fertil Steril 2012;6(2):131-4.

4. Feit H, Leibovitz Z, Kerner R, Keidar R, Sagiv R, Ovarian pregnancy following IVF, in a woman after bilateral salpingectomy. A case report and review of the literature, The Journal of Minimally Invasive Gynecology (2015) doi: 10.1016/j.jmig.2015.01.018. 
5. Iwama H, Tsutsumi S, Igarashi H, Takahashi K, Nakahara K, Kurachi H. A case of retroperitoneal ectopic pregnancy following IVF-ET in a patient with previous bilateral salpingectomy. Am J Perinat 2008;25(1):33-6.

6. W. P. Dmowski, N. Rana, J. Ding, and W. T. Wu. Retroperitoneal Subpancreatic Ectopic Pregnancy Following In Vitro Fertilization in a Patient with Previous Bilateral Salpingectomy: How Did It Get There? J Assist Reprod and Genetics 2002;19(2):903.

7. Assisted reproductive technology in the United States: 2001 results generated from the American Society for Reproductive Medicine/Society for Assisted Reproductive Technology registry Society for Assisted Reproductive Technology and the American Society for Reproductive Medicine. Fertil Steril 2007;87:1253-66.

8. Marcus SF, Brinsden P. Analysis of incidence and risk factors associated with ectopic pregnancy following in-vitro fertilization and embryo transfer. Hum Reprod 1995;10:190-203.

9. Po-Chun K, Ching-Chung L, Tsia-Shu L, Hong-Yuan H. Six cases of tubal stump pregnancy: complication of assisted reproductive technology? Fertil Steril 2011;95:2432,e1-e4.

10.Karen ES, Lisa B, James PT,Sergio O, Suheil JM. Salpingectomy improves the pregnancy rate in invitrofertilization patients with hydrosalpinx.Human Reproduction 1996;11:523-5.

11.Mandakini P, Aparna M, Reshma H. Hydrosalpinx functional surgery or salpingectomy? The importance of Hydrosalpinx fluid in assisted reproductive tecnologies. J Gyn Endos Surg 2009;1:12-6.

12.Takeda, S. Manabe, T. Mitsui, H. NakamuraSpontaneous ectopic pregnancy occurring in the isthmic portion of the remnant tube after ipsilateral adnexectomy: report of two cases. J Obstet Gynaecol Res 2006;32:190-4.

13.Bernardini, M. Valenzano, G. Foglia Spontaneous interstitial pregnancy on a tubal stump after unilateral adnectomy followed by trasnvaginal colour Doppler ultrasound Hum Reprod 1998;13:1723-6.

14.S.K. Agarwal, A.L. Wisot, G. Garzo, D.R. MeldrumCornual pregnancies in patients with prior salpingectomy undergoing in vitro fertilization and embryo transfer. Fertil Steril 1996;65:659-60.

15.Claudi A, Hansen CS, Nørgaard LN. Lifethreatening extrauterine pregnancy after in vitro fertilization and bilateral salpingectomy. Ugeskr Laeger. 2015;177/2A:112-3. 